\title{
Transgenic Residues in Soybean-based Foods
}

\author{
Mónica L. Chávez-González, Carolina Flores-Gallegos, \\ Víctor M. García-Lazalde, Cristóbal Noé Aguilar \\ and Raúl Rodríguez-Herrera \\ Food Research Department. School of Chemistry. \\ Universidad Autónoma de Coahuila \\ México
}

\section{Introduction}

The technology of genetically modified foods (also called GM foods) allows selection of an specific genetic trait from one organism and introduces it in the genetic code of the food source through genetic engineering techniques. This has made possible to develop food crops with specific beneficial traits and elimination of undesirable traits in others. In spite of the great agricultural advantages of transgenic crops these do not have acceptance in some countries because: a) the suspicious of consumer as result of allergic reactions observed with some transgenic crops, b) the lack of worldwide regulations to these crops, and c) the negative side effects to environment by the massive farming of transgenic crops, for example loss of genetic diversity, creation of higher adapting weeds, the migration of transgenic genes to their wild relatives and less likely migration of transgenic genes to other unrelated organisms by horizontal transference. Also, the contamination of food with transgenic residues has persuaded different countries to restrict importation of food made with transgenic plants or labelling food or ingredients as or from transgenic crops.

There are worrying aspects about the effect of transgenic food over human health such as: 1 ) many of transgenic genes used today have never been present in human diet, making impossible to know the effect that they will cause, 2) the allergic potential of some proteins codified by some transgenic genes, and 3) in the genetic engineering of crops, many times a gene with antibiotic resistance is included like selectable gene, having the possibility that this gene migrates to pathogen bacteria that affect the health of plants, human and animal, developing bacterial resistance to those antibiotics making hard to have bacterial control. In the present work, literature is reviewed in order to present a perspective about some of the above concerns. In addition, are presented results of different studies in order to answer the following questions: a). Do DNA and proteins are degraded during the traditional soybean food processing?, b). Does food processing affect the persistence of transgenic residues? and c) Does is possible to develop more efficient techniques for detection of transgenic residues in soybean-based foods? 


\section{Transgenic seeds in the world market}

The global food demand has increased the need for improved crops. At 2006 the biotechnological industry reached several goals, for example, the annual area planted with transgenic crops exceeded for first time 100 million hectares; the number of farmers whom cultivate biotechnological crops exceeded 10 million (10.3), where it is important to stand out that $90 \%$ of these farmers were of scanty resources in developing countries whom increased their income across this crops helping to relieve this way their poverty; the accumulated area from 1996 to 2006 exceeded the half trillion of hectares, with an increase without precedent of 60 times between 1996 and 2006, doing this agricultural technology the most rapidly adopted in the recent history (James, 2006). Inside transgenic crops and food that now exist on the market, four are the most important: maize, cotton, soybean and canola. These transgenic products are recent on the world market; since 1996 they were planted freely in The United States of America (USA).

In USA during 2006, 54.46 million of hectares of transgenic crops were sown, principally soybean, maize, cotton, canola, gourd, papaya and alfalfa, followed by Argentina, 18.0 million (soybean, maize and cotton), Brazil with 11.5 million, Canada with 6.1 million, India with 3.8 million of transgenic cotton, China with 3.5 million, Paraguay with 2.0 million ha of transgenic soybean, and SouthAfrica with 1.4 million of hectares of transgenic maize, soybean and cotton. There are a group of countries that sown less than 100000 hectares of transgenic crops such as: Colombia, France, Iran, Portugal and Honduras, where the predominant crop is maize, and one more group of countries like Uruguay, The Philippines, Australia, Romania, Mexico and Spain where less than one million hectares are cultivated (Massieu-Trigo, 2009). At the present time the most common genetic transformations in these transgenic crops are basically two: tolerance to herbicides and resistance to insects.

In the USA, the area planted with transgenic soybean was estimated as 77.5 million ha during 2009, $2 \%$ more with regard to 2008. Compared with 2008 there was an increase in the surface planted by 200, 000 ha or more in Kansas, Mississippi, Missouri, North Dakota and South Dakota. The major decrease happened in Nebraska, up to 400, 000 ha with regard to 2008. The record of the major planted surface was estimated for Kansas, New York, North Dakota and Pennsylvania (NASS, 2009).

Although big advances have been achieved in the last years for transgenic crops adoption, it still persists distrust over of these products, which has limited the adoption of these technologies by many small farmers, mainly for five reasons:

- The investments in transgenic crops by the private sector

- The public expenditure on these technologies

- $\quad$ Limited access to patent technologies

- Constant worries on food safety and risks to environment

- Weak capacity of regulation in developing countries

In addition to the previous limitations, a great controversy persists in rich countries especially the European Union where the principal points in this controversy are the safety of environment, food health and social risks of genetically modified organisms (GMO); nevertheless this situation must not conceal the potential of these products to contribute in poverty reduction among farmers from developing countries, where GMO can play an important role in the small scale agricultural systems and provide nourishing food for the poor consumers in developing countries (Ragasa \& Pehu, 2008). 


\section{Transgenic crops in Mexico}

Genetically modified products are on top of an agro-political debate, mainly as a result of concerns based on the consumers food safety issues such as the result of eating a GMO (Ash et al., 2003). Mexico is one of the countries that most import grain seeds, and permissions to plant transgenic crops have been released by official agencies. For example, in the state of Coahuila, transgenic cotton have been planted since 1997; in the state of Chiapas has been planted transgenic soybean and transgenic tomato with delayed ripening characteristics has been sown in Guasave, Sinaloa, among others (Castro-Soto \& Zinn, 2001; Macias-de la Cerda, 2006). In 1989, a National Agricultural Biosafety Committee was created in Mexico as an institution to approve the release of genetically modified organisms and products to environment and Mexican market, and also establish policies and regulations on GMOs. Ten years later the government of Mexico created the Commission on Biosafety and Genetically Modified Organisms (CIBIOGEM) in order to coordinate policies on biosecurity, production, import, export, mobilization, propagation, liberation, consumption, use and development of GMOs products and by-products (Cantu-Iris, 2006).

In Mexico, many GM products are consumed without being aware of it. Corn and soybeans are being used as ingredients for food products (vegetable oils, bread, flour, milk, ice cream, etc.). Soybean is present in more than $60 \%$ of these products (Castro-Soto \& Zinn, 2001). GM crops in Mexico during the period from 1996 to 2009 were grown in 16 states. Among the companies that have obtained permits for planting GM crops in this state are Excerpts Agro, Monsanto and IARC. In Sinaloa, tomato, zucchini, corn, melon, cotton, chile and soybean have been cultivated. Among the companies that have obtained permits for planting GM crops in this state are: Campbells, Sinalopasta, Calgene, Asgrow Mexicana, Monsanto, Harris Moran of Mexico, DNA Plant Technology, Peto Seed, Pioneer and Rhone Poulenc. In the State of Guanajuato were grown potatoes, tomato, squash, corn, rice and wheat. Among the companies and institutions that have obtained permits for planting of GM crops in this state are: CINVESTAV, UpJhon Asgrow, ISK BioSec, Seminis Vegetable Seeds, PetoSeeds, Asgrow and the National Autonomous University of Mexico (UNAM). While in Veracruz have been planted, cotton and soybeans. Among the companies that have obtained permits for planting of GM crops in this state include: CIBA-GEIGY and Monsanto.

In Baja California have been cultivated tomatos, cotton, pepper, squash, melon, canola and flax. Among the companies that have obtained permits for planting of GM crops in this state are: PetroSA Mexican Agritope, Aventis CropScience, Seminis Vegetable Seeds, Monsanto, DNA Plant Technology, and SVS Mexicana Calgery. In the State of Mexico have been planted wheat, corn, alfalfa and carnation. Among the companies and institutions that have obtained permits for planting of GM crops in this state include: CIMMYT, Florigene CEFINI-UNAM and Europe BV. In other states, like Tamaulipas, cotton and soybeans have been planted. Among the companies that have obtained permits for planting of GM crops are: Malvinas, Monsanto, Rhone Poulenc and Avenis Cropscience. In Baja California Sur have been grown tomato, zucchini, tomatoes, melons, corn and cotton. The companies that have obtained permits for planting GM crops in this state include: Agritope, Asgrow Mexicana, Seminis Vegetable Seeds, Pioneer, SVS Mexicana, DNA Plant Technology and Monsanto. While in Morelos has been planted maize by CIMMYT, in Jalisco have been sown soybean, potato, tomato, pepper, maize, and also have been tested genetically modified microorganisms. Among the companies and institutions that have obtained permits for the planting of GM crops in this state are: Hybrid Seeds SA de CV, CINVESTAV, CIBA-GEIGY 
Mexicana, Technology and Asgrow Plant DNA. In Coahuila was grown cotton and soybeans by Monsanto Company and CINVESTAV. In Sonora have been planted canola, potato, tomato, cotton, corn, soybean and melon. Among the companies that have obtained permits for the planting of GM crops in this state include: Calgene, CINVESTAV, DNA Plant Technology, Harris Moran, Monsanto, Mycogen Mexicana and Rhone Poulenc. In Nuevo Leon, squash was planted by PetoSeeds and Seminis Vegetable Seeds. In San Luis Potosi were planted cotton and soybeans by Monsanto. In Chihuahua was reported the planting of cotton by Monsanto, while in Nayarit were planted soybeans, maize and tomato by Pioneer, Monsanto, Zeneca and Asgrow.

In 2006, the area planted with soybean in Mexico was 0.1 million ha from which 0.005 million hectares were GM soybean. Soybean production in Mexico is not enough to satisfy domestic demand hence the import of this leguminous is a necessity, mainly from USA, Argentina and Brazil (Cruz-Flores, 2005). Nowadays, Mexican regulation does not require labeling of products produced from or with genetically modified raw materials. This situation promotes public debate because some scientifics state that the primary reason for avoiding genetic modification in food is the great uncertainty that exists around these products, bringing with it consequences, for example, that consumers neither have the right to choose which product to consume nor strict control of diseases caused by these products, so as to generate a complaint against the companies if they generate harmful effects on the health of consumers (Castro-Soto \& Zinn, 2001). The labeling of GM food products has become a major battleground between the biotechnology industry and society (Cruz-Flores, 2005).

\section{Risks associated with the transgenic seeds}

The use of GMO's must be done based on a rigorous analysis of the risks that they could represent for environment, biodiversity and human health. Though commonly risks related to socioeconomic and cultural activities are not evaluated explicitly, these also can play an important role in making decisions. It is difficult to identify all adverse effects that can happen. Nevertheless, it turns out to be an illustrative exercise to identify and to measure some of the attributes that can be associated with possible adverse effects, in the different levels of biological complexity. Modified crops can present consequences in the survival, reproduction, competitive capacity or interactions with other organisms. The most serious ecological risks that present the commercial use of transgenic crops are: the expansion of the transgenic crops threatens the genetic diversity for the simplification of the systems of crops and the promotion of the genetic erosion (Rissler \& Mellon, 1996; Krimsky \& Wrubel, 1996). The potential transfer of genes from crops resistant to herbicides (CRHs) to wild varieties or semi-domesticated relatives could make the control of these wild relatives more difficult or reduce the biodiversity of these plant species. Recombination of vectors which could generate varieties of virus more harmful, especially in GM plants designed for viral resistance on the basis of genes viral, and that the plagues of insects will develop rapidly resistance to the transgenic crops.

The history has showed that a large area cultivated with an alone crop is very vulnerable to new pathogenic or plague, the widespread use of an alone crop leads to the loss of genetic diversity (Robinson, 1996). There exist evidences that do not leave any doubt that cultivation of large areas with few modified varieties has been an important reason of the genetic 
erosion, when the governmental massive campaigns encourage the farmers to adopt modern varieties pushing them to leave a lot of local varieties (Tripp, 1996). The uniformity caused by the increase of the area of crop with a number of smallest varieties is a source of risk for the farmers, when the modern varieties are more vulnerable to diseases and to the assault of plagues (Robinson, 1996).When an alone herbicide is used repeatedly on a crop, the opportunities of which resistance develops to the herbicide in the population of weeds increases (Holt et al., 1993). Cassia obtusifolia, an aggressive weed in the soybean and the maize cropping in the Southeast of the USA has exhibited resistance to the herbicide imidazolinone (Goldburg, 1992).

Some risks involved in the consumption of GM soybean have been reported. Marshall (2007) indicated the relation of a diet based on resistant soybean to glyphosate and low possibilities of survival at birth. Also, there have been associated allergic reactions to the consumption of modified soybean (Burks et al., 1988; Ogawa et al., 1993; Burks \& Fuchs, 1995). Nevertheless Batiste et al. in 2005, reported a study where volunteers did not showed allergic reaction after consumption of modified soybean and modified maize. Nevertheless, the benefits of the modified soybean exceed in much to the adverse effects.

\section{Benefits of the transgenic soybean}

Traditionally soybean based-foods of have been consumed for centuries in most of the Asian countries and recently, this food has had a great popularity in the west hemisphere (Messina, 2008), this popularity is because reports on soybean bioactives components which may have effects on disease prevention as well as in the treatment of some diseases. Soybean products contain bioactives phytochemicals such as isoflavones, saponins, phytic acids, phytosterols, trypsin inhibitors and peptides (Isanga \& Zhang, 2008). The isoflavones are classified like phytoestrogens and have been postulated for being natural alternatives for the hormonal therapy for woman menopause (Messina, 2008). Some investigations have involved the phytochemicals contained in soybean as functional in the reduction of cholesterol and prevention of: cardiovascular diseases, diabetic symptoms, bone lose straight and cancer (Isanga \& Zhang, 2008). Regarding cardiovascular diseases, it has been suggested that soybean-based food can help to reduce the levels of cholesterol; soybean will help to this change since provide quality protein, in addition is low in saturated fat and is devoid of cholesterol (Messina \& Lane, 2007).

Some studies reports that transgenic soybean with high content of a-tocoferol by expressing the gene $\gamma$-tocoferol metiltransferase of Perilla frutescens (Tayva et al., 2007), could have a role on prevention of lipids oxidative damage during seed storage and germination, besides an increase of a-tocoferol content might have a potential to increase vitamin E consumption in diet. Nevertheless some bioactives compounds in soybean are brought for possessing some adverse effects to human health (Isanga \& Zhang, 2008).

Besides the benefits of soybean on health it is important to stand out the importance of genetically modified soybean as a crop. In transgenic soybean the principal characteristics incorporated are: resistance to insects and herbicide tolerance which are based on the cry and epsps (synthetase 5-enolpyruvylshikimate-3-phospahte) genes, respectively (Rincon et al., 1999). Because this type of modifications, soybean can resist to adverse circumstances, which contribute to improve of the earnings. This type of technologies was adopted since 1996 in USA, where soybean tolerant to glyphosate was introduced; this soybean had a great adoption by farmers (Dill et al., 2008). Glyphosate known commercially as Roundup ${ }^{\circledR}$ acts 
in all vegetable species, inhibiting the enzymes essential for synthesis of aromatic amino acids. These amino acids are necessary for photosynthesis. When these amino acids are not able, plant die or stop their growth. This GM soybean could tolerate glyphosate applications; this tolerance is conferred by a bacterial enzyme (Malik et al., 1989; Barry et al., 1992). The employment of this type of transgenic crops represents one of the technologies of more quickly adoption for weed control (Dill et al., 2008). There has been demonstrated that the technology of modified organisms increases the total productivity of factors in $10 \%$, provoking cost saving, reduction in the use of toxic herbicides and involve positive repercussions in environment (Qaim \& Traxler, 2005).

\section{Most common transgenic sequences incorporates to soybean}

Weed control is a critical step in soybean cropping. For effective control of weeds, farmers commonly selected herbicides, based on several factors: cost, environmental risks, weeds and crop damage. Advances in plant biotechnology have made possible to insert genes into soybean conferring specific tolerance to herbicides and providing benefits to weed control in soybean fields. Glyphosate-tolerant soybeans may impact general agronomic practices on soybean, offering to farmers a new option for broad spectrum weed control. The development of crops tolerant to glyphosate has been pursued since the early 1980, the mechanism of change in site was used for soybeans, where a protein target insensitive to the herbicide was identified and introduced into the crop through genetic engineering techniques (Padgett et al., 1995). With similar techniques were generated soybean varieties that produce high amounts of fatty acids and oleic acid generated by the transfer of a second copy of the gene for soybean-fatty-acid desaturase (GmFad2-1) by biolistic transformation of soybean. In addition, soybean varieties have been transformed in order to develop disease and insect resistance. The control of plant pathogens is a major challenge for the agricultural industry, because they are responsible for large economic losses annually.

\subsection{Herbicide tolerant soybean}

The specificity of glyphosate blocking the activity of 5-enol-Pyruvyl-Shikimate-3-Phosphate Synthase (EPSP synthase), which catalyzes the reaction of shikimate -3-phosphate (S3P) and phosphoenolpyruvate (PEP) of 5-enol-pyruvyl-shikimate-3-Phosphate (EPSP) and phosphate. Glyphosate inhibition of EPSPS prevents the plant to produce an aromatic amino acid essential to protein synthesis and some secondary metabolites (Padgett et al., 1995). The EPSPS enzyme is present in all plants, bacteria and fungi, but not in animals, which do not produce their own aromatic amino acids. In plants, EPSPS is localized in chloroplasts or plasmids, in the treatment of glyphosate, genetically modified crops remains unaffected due to the constant action of the enzyme EPSPS tolerant meets the needs of aromatic amino acids of the plant.

On the other hand, the bar gene confers tolerance to glyphosate ammonium, and this was cloned from a common soil actinomycete Streptomyces hygroscopicus and encodes for the phosphinotricin $\mathrm{N}$ acetylase (PAT) enzyme that detoxifies the phosphinotricin enzyme by acetylation in an inactive compound. This kind of herbicide-resistant soybeans comes with a reporter gene that encodes for the enzyme beta-D-glucuronidase (GUS) used development to select the transformed plants during tissue crop regeneration and multiplication. Genetic modification was made by the biolistic technique, using transcriptome-derived sequences of virus 35S cauliflower mosaic (CaMV), (GM Crop Database ACS-GM003-1, ACS-GM001-8, 
ACS-GM002-9 GM-005 ACS-3, GM-006-ACS 4, 2010). Other crops engineered for tolerance to herbicides are those that express a protein AtHASL altered (which is structurally similar to AtHASL native, except for the replacement of asparagine at position 653) encoded by the gene csr1-2 of Arabidopsis thaliana, which confers tolerance to imidazolinone (GM Crop Database BPS-CV127-9).

\subsection{Fatty acid content modifications}

The soybean with high oleic oil production contains high levels of oleic acid greater than that found in olive and canola oil. This kind of soybean was achieved using the endogenous gene GmFad2-1. This genetic modification affects seeds and other plant parts like leaves. These changes result in more oil, more stable to heat with enhanced nutritional and functional properties. Other features transferred with the GmFad2-1 gene and the uidA (a colorimetric marker used for selection of transformed plant lines during the processing of soybeans) that encodes for beta-glucuronidase enzyme, derived from the bacterium Escherichia coli. And the bla gene (a marker used for selection of transformed bacteria from non transformed during the cloning of recombinant DNA and steps that are performed in the laboratory prior to the transformation of plant cells) that encodes the enzyme beta lactamase that confers resistance to some beta-lactam antibiotics such as penicillin and ampicillin (GM Crop Database DD 026005-3, 2010). Pioneer used a technique of microprojectile bombardment for secondary embryos co-transforming plant cells with two purified DNA fragments, the PHP19340A (fragment of $2924 \mathrm{bp}$ ) containing the Gm-Fad2 gene-1 (includes the promoter for the Kunitz trypsin inhibitor gene (KTi3)) and the PHP17752A gene (fragment of $4512 \mathrm{bp}$ ) containing the Gm-Hra gene and gene fragments inserted and microsomal omega-6-desaturase that results in the endogenous expression of this enzyme, with the intention of produce soybeans containing monounsaturated fatty acids (oleic oil) (GM Crop Database, DP-305423-1, 2010).

\subsection{Crops resistant to viral and fungal resistance}

To obtain transgenic plants resistant to viral diseases it has been used pathogen-derived genes, introduced into the plant. Viral genes have been transferred to crops to limit the ability of invaders to replicate within plant cells, this strategy induces resistance to viral diseases and opens new possibilities for the effective control of these diseases. Besides, it has been developed plant varieties resistant to fungal attack, by inserting genes of resistance, once the resistant plant, and the genes persist in future generations through conventional breeding procedures (Macias-de la Cerda, 2006).

\subsection{Insect-resistant crops}

Most of the inserted genes into plants for insect resistance have been isolated from Bacillus thuringiensis, a soil bacterium whose spores contain a crystalline protein (cry) which when ingested by an insect decomposes and releases a toxin called endotoxin delta. The toxin is embedded in the walls of insect gut creating pores, resulting in ionic imbalance and paralysis to the insect digestive system. It has been identified versions of these genes effective against different orders of insects (Cantu-Iris, 2006). Bth toxins are not toxic either to humans or environment, each strain produces proteins that have a specific effect on certain species of insects, usually within the same order (Table 1) (Macias-de la Cerda, 2006). 


\begin{tabular}{|c|c|}
\hline Gene & Order of susceptible insects \\
\hline cryIA(a), cryIA(b), cryIA(c) & Lepidoptera \\
\hline cry $1 \mathrm{~B}, c r y 1 \mathrm{C}, c r y 1 \mathrm{C}$ & Lepidoptera \\
\hline cry II & Lepidoptera, dipteran \\
\hline cry III & Coleoptera \\
\hline cry IV & Dipteran \\
\hline cry IV & Lepidoptera, coleptera \\
\hline
\end{tabular}

Table 1. Specificity of the toxins encoded by different $B t$ genes

\section{Transgenic residues in soybean-based foods}

The main features introduced to transgenic crops are: resistance to different species of insect pests, and tolerance to certain herbicides, all this is achieved by introducing to soybean plants one or more genes that confer to these plants that characteristics. In 2002, a study was initiated to determine if a). Do DNA and proteins are degraded during the traditional soybean-based food processing?, b). Does soybean food processing affect the persistence of transgenic residues? and c). Does is possible to develop more efficient techniques for detection of transgenic residues in soybean-based food?

\subsection{Do DNA and proteins are degraded during traditional soybean food processing?}

In the Universidad Autonoma de Coahuila, 22 lots of soybean imported to Mexico from different countries were analyzed by PCR. PCR was carried out using specific primers for accompanying transgenic sequences (ubi,35S, ntpII, bar, gus, luc, us, ocs) and 9 transgenic events (cry1ab, cry1e, cry $2 A$, cry3 $A$, cry $11 A$, epsps, als, ec, accasa). Results showed that all the analyzed samples presented at least one transgenic sequence. The most frequently $(90 \%)$ detected promoter in the imported soybean was $u b i$. The marker most detected in the samples was bar in $75 \%$ of the samples, while the reporter most detected was $l u c$ in $45 \%$ and the terminators ocs and nos were detected in $45 \%$ of the samples. On the other hand, the most detected transgenic event was epsps in $100 \%$ of the cases. The results suggest that the great majority of soybean lots that Mexico imports are mixtures of soybean genetically modified varieties (Macias-de la Cerda, 2006 and Cantu-Iris, 2006). The importance of analyzing grain shipments imported into a determined country is because is important to determine the level of contamination of these grains with GM crops, the potential risk for the native biodiversity and pollution of native grain production (Padgett et al., 1995; Cantu-Iris, 2006). With the above mentioned soybean lots were elaborated different traditional soybean-based foods and critical steps of food processing (drastic changes in temperature and $\mathrm{pH}$ ) were identified. DNA was extracted from the samples of each critical step. Segments of epsps, cry A1 genes and CaMV promoter were amplified by PCR from tofu, milk, yogurt, sausage, flour and soybean sprouted. This work identified the presence of the promoter in $45 \%$ of the samples and the gene cry $1 \mathrm{~A}$ in $35 \%$ of the samples. This suggested that processing conditions of traditional soybean-based foods did not affect the transgenic segment persistence (Gonzalez, 2004). 


\subsection{Does food processing affect the persistence of transgenic residues}

Commercial food products from major cities of Coahuila, Mexico were screened to identify residues of transgenic DNA and/or proteins. After performed, an inventory on all products that contained a soybean-based ingredient in a commercial grocery store in the city of Saltillo, Coahuila, Mexico, two hundred and forty five food products were identified and grouped in 15 classes according to the soybean ingredient as well as the manufacturing process used for their elaboration. Similar sampling was made for the different food classes in the cities of Monclova, Piedras Negras and Torreon. Segments of the transgenic genes epsps, cry 1A and the CaMV promoter were amplified using PCR. The transgenic proteins 5enolpyruvylshikimate-3-phosphate synthase (CP4 EPSPS) and an insecticidal crystal protein (Cry $1 \mathrm{Ab} / \mathrm{Ac}$ ) were identified using DAS-ELISA (Double antibody sandwich - Enzymatic Linked Immunoassay Analysis). Presence of transgenic genes and/or proteins was identified in $35.3 \%$ of the commercial products samples (Cruz-Flores, 2005). It was observed the presence of transgenic residues in foods with different levels of processing (Table 2 and 3 ). Table 2 presents the list of the 15 different classes of commercial products based on soybean ingredients; Table 3 presents a list of products were the presence of cry and epsps genes and CP4-EPSPS and CRY $1 \mathrm{AB} / 1 \mathrm{Ac}$ proteins were detected (Cruz-Flores, 2005).

\subsection{Is it possible to develop more efficient techniques for the detection of transgenic residues in soybean-based foods?}

Macias-de la Cerda (2006) reported the development and optimization of a multiplex-PCR protocol for the simultaneous detection of three accompanying transgenic sequences. Multiplex PCR was performed with DNA from soybean plants for the detection of transgenic sequences, allowing the amplification of nos (125 bp), ntpII (271bp) and luc (450 $\mathrm{bp)}$ at an annealing primers temperature of $62^{\circ} \mathrm{C}$. In this case a multiplex PCR technique based on amplification of the accompanying transgenic sequences could be a very valuable tool for detecting DNA transgenic residues. On the other hand Cantu-Iris (2006) reported the optimization of a multiplex PCR for detection of two or more transgenic sequences. The primers sequence was evaluated in order to avoid the primer dimmer formation. Eighteen primers were evaluated with the software FastPCR ${ }^{\circledR}$ and only three primer interactions were observed, which must be avoided for multiplex PCR. The simultaneous amplification of three of the most common transgenic events (cry 1Ab, epsps and als) in a same reaction was obtained with a optimized multiplex PCR. These results could have an impact on a more efficient (speed and cost) detection of genetically modified organisms.

\subsubsection{Corroborating the efficiency of multiplex PCR for detecting accompanying sequences and transgenic events in commercial food}

Hernandez (2007) reported detection of simultaneously different transgenic residues from DNA of home-making and distributed commercially soybean-based foods using the multiplex PCR technique. Pairs of specific primers for the events epsps, cry $1 \mathrm{Ab} / 1 \mathrm{As}$, and als and for the accompanying sequences nos, luc and ntp II were used. The soybean samples identified as transgenic were used to elaborate three soybean-based foods (milk, sausages and tofu). In addition, 20 commercial foods with at least one soybean ingredient were used for DNA extraction. It was possible to detect simultaneously three transgenic events (epsps, als and cry $1 \mathrm{~A} / \mathrm{b}$ ) and three accompanying transgenic sequences (epsps, als and cry $1 \mathrm{~A} / \mathrm{b}$ ) from DNA isolated from commercial and homemade soybean-based foods. 


\begin{tabular}{|c|c|c|}
\hline Soybean class & Typical product & Product Characteristics \\
\hline Soybean oil & Soybean oil & Soybean $100 \%$ \\
\hline Vegetal oil & Vegetal oil & $\begin{array}{c}\text { Mixture of oils from soybean and } \\
\text { other plants. }\end{array}$ \\
\hline Others oil with lecithin & Vegetal oil & $\begin{array}{l}\text { Vegetal oil with soybean as } \\
\text { additive }\end{array}$ \\
\hline $\begin{array}{l}\text { Products with soybean oil and } \\
\text { without heat treatment }\end{array}$ & $\begin{array}{l}\text { Salad seasoning, } \\
\text { mayonnaise }\end{array}$ & $\begin{array}{l}\text { No use of temperature for food } \\
\text { processing. }\end{array}$ \\
\hline Soybean oil with heat treatment & $\begin{array}{c}\text { cereal, bread, flour, } \\
\text { cookies chocolate, } \\
\text { cheese, French potatoes }\end{array}$ & $\begin{array}{l}\text { Use of temperature for food } \\
\text { processing. }\end{array}$ \\
\hline $\begin{array}{l}\text { Soybean lecithin without heat } \\
\text { treatment }\end{array}$ & Frozen dessert & \begin{tabular}{|c|} 
Soybean lecithin as emulsifier \\
/anti oxidant and no use of \\
temperature for food processing.
\end{tabular} \\
\hline $\begin{array}{l}\text { Soybean lecithin with heat } \\
\text { treatment }\end{array}$ & $\begin{array}{l}\text { Chocolate, candies, } \\
\text { bread, soup, cookies }\end{array}$ & $\begin{array}{c}\text { Soybean lecithin as emulsifier } \\
\text { / anti oxidant and use of } \\
\text { temperature for food processing. }\end{array}$ \\
\hline $\begin{array}{c}\text { Hydrolyzed soybean } \\
\text { protein/soybean sauce without } \\
\text { heat treatment }\end{array}$ & Sauces, seasoning. & \begin{tabular}{|c|}
$\begin{array}{c}\text { No use of temperature for food } \\
\text { processing and protein/sauce is } \\
\text { used as flavoring }\end{array}$ \\
\end{tabular} \\
\hline $\begin{array}{c}\text { Hydrolyzed soybean } \\
\text { protein/soybean sauce with heat } \\
\text { treatment }\end{array}$ & $\begin{array}{l}\text { Chocolates, cereals, } \\
\text { soup, peanut, chips }\end{array}$ & $\begin{array}{c}\text { Use of temperature for food } \\
\text { processing and protein/sauce is } \\
\text { used as flavoring }\end{array}$ \\
\hline Soybean flour & Bread, flour & Soybean flour as an ingredient. \\
\hline Isolated soybean protein & $\begin{array}{c}\text { Cereal, bread, sausage, } \\
\text { meta }\end{array}$ & $\begin{array}{l}\text { Containing more than } 90 \% \text { of } \\
\text { soybean proteins. }\end{array}$ \\
\hline Textured soybean & $\begin{array}{l}\text { Imitation of bacon, } \\
\text { tuna, sausage }\end{array}$ & $\begin{array}{c}\text { Fibrillated proteins imitating beef } \\
\text { tissue texture. }\end{array}$ \\
\hline Soybean without specifications & Cereal, chips, beverages & $\begin{array}{l}\text { Soybean is only mentioned in the } \\
\text { product label. }\end{array}$ \\
\hline Active enzymes & Tortilla & \\
\hline Soybean concentrate & Sausage & $\begin{array}{l}\text { Containing about } 70 \% \text { proteins } \\
\text { from soybean. }\end{array}$ \\
\hline
\end{tabular}

Table 2. Fifteen different classes of commercial products based on soybean-ingredients evaluated by Cruz-Flores (2005) 


\begin{tabular}{|l|c|c|c|c|c|}
\hline \multicolumn{1}{|c|}{ PRODUCT } & EPSPS & $35 S$ & cry1A & $\begin{array}{c}\text { Protein } \\
\text { CP4 } \\
\text { EPSPS }\end{array}$ & $\begin{array}{c}\text { Protein } \\
\text { Cry } \\
\text { 1Ab/1Ac }\end{array}$ \\
\hline Hot cakes flour 1 & - & + & + & + & - \\
\hline Hot cakes flour 2 & + & + & - & + & - \\
\hline Salad seasoning & - & - & + & + & - \\
\hline Salad cookies & - & - & + & - & - \\
\hline Chocolate bar & - & + & - & + & - \\
\hline Imitation of bacon & - & + & - & + & - \\
\hline Sausage & + & - & - & + & - \\
\hline Tortillas & - & + & - & + & - \\
\hline Powder for drinks & - & + & + & + & - \\
\hline Oat cereal & + & - & - & + & - \\
\hline Powder chocolate & - & + & + & + & - \\
\hline Flour for chocolate cake & + & + & - & + & - \\
\hline Turkey sausage & - & + & - & + & - \\
\hline Peanut snacks & - & - & - & + & - \\
\hline Seasoning with chesse & - & - & - & + & - \\
\hline Bread & - & - & - & + & - \\
\hline Cookies & - & - & - & + & - \\
\hline Instantaneous soup & - & + & - & - & - \\
\hline Bread $(M)$ & - & + & + & - & - \\
\hline Salad cookies $(M)$ & - & + & - & - & - \\
\hline Cookies $(M)$ & + & - & - & - & - \\
\hline Turkey sausage $(M)$ & - & + & + & - & - \\
\hline Peanut snacks $(T)$ & - & + & - & - & - \\
\hline Hot cakes flour $(T)$ & + & + & - & + & - \\
\hline Dust chocolate $(T)$ & - & + & + & - & - \\
\hline Salad cookies $(P)$ & - & + & + & - & - \\
\hline Peanut snacks $(P)$ & - & + & - & - & - \\
\hline Bread $(P)$ & - & + & + & - & - \\
\hline Instantaneous soup $(P)$ & - & + & - & - & - \\
\hline Hot cakes flour $(P)$ & + & + & - & + & + \\
\hline & + & + & + & + \\
\hline
\end{tabular}

Table 3. Identification of cry genes, EPSPS CP4-EPSPS protein and cry1AB/1AC in some commercial food products based on soybean (Cruz-Flores, 2005).

\section{Detection of transgenic residues in soybean-based food}

In modern agriculture, soybean is considered one of the most profitable crops due to nutritional properties. The soybean contents up to $20 \%$ of high quality oil for human consumption. This makes soybean a product of great importance in manufacturing food products such as milk, food supplements, vegetables and other derivatives, and mixtures of beef with soybean, reducing significantly costs and improving nutritional quality.

In the world, this type of soybean occupied $60 \%$ of the planted area of biotech crops (Germini et al., 2004b).In recent years, genetically modified organisms (GMOs) have 
attracted great interest and many policy debates about its impact on environment and the safety of genetically modified plants and foods (Germini et al., 2004b). The identification of GMOs has become a topic of great interest as the number of products derived from GMOs that have been released to the market has increased, also has increased demands by consumers for strict regulations on the labeling of these products (Feriotto et al., 2002).

The European Union (EU) has regulations since 1997 for labeling products containing more than $0.9 \%$ Roundup Ready soybean (Reg. 49/200/EEC), as well as additives and flavorings from GM crops (Reg. 50/2000/EEC) (Germini et al., 2004a). In Mexico, on March 18, 2005 the Law on Biosafety of Genetically Modified Organisms (DOF 18/03/2005) was published in the Federation official journal. The scientific community's interest in the development of efficient methodologies for the detection of GMOs is related to the fact that they agree on the need for highly automated detection systems for identification of GMO-free food as well as quantitative tests to verify levels of GMOs in food (Feriotto et al., 2002). Two techniques have been developed mainly for the detection of GMOs: DNA analysis by PCR and protein analysis (Germini et al., 2004b).

\subsection{Techniques based on DNA identification 8.1.1 Polymerase chain reaction (PCR)}

This technique is an enzymatic method that allows copying a particular area of a genome, being able to get up to thousand copies in a test tube. PCR uses DNA polymerase which is able to copy DNA molecules. The technique requires a known nucleotide sequence of a desired gene region, since the PCR needs short oligonucleotides or primers, complementary to sequences present in the gene or genes of interest from which the DNA polymerase will incorporate nucleotides complementary to the chain being copied (Germini et al., 2004b). Vobllenhofer et al. (1999) designed primers to amplify parts of the 355 promoter, NOS terminator and marker NTPII. PCR / hybridization protocols were established for detection of Roundup Ready soybeans. In addition to hybridization, confirmation of results was possible using a restriction analysis. The aim of this work was to select pairs of primers that allow the restriction enzyme digestion of PCR products using inexpensive enzymes to reduce costs of analysis. None of the amplified fragments was greater than $200 \mathrm{bp}$, so the analysis of DNA from highly processed foods was not a problem. This procedure was highly sensitive and specific for detection of GMOs and provides a useful tool in the analysis of raw materials and processed foods. Jeng et al. (2006) analyzed soybean seeds and their products for detecting Roundup Ready soybean traces. Most soybean products were generated using a heating process, which damages the DNA used for PCR reaction. However, amplification was achieved for the detection of transgenic soybean using epsps, lectin and $35 \mathrm{~S}$ genes. Fermentation is another important part of the process of soybean-based products, where the DNA after a long period of fermentation (over 180 days) is severely damaged. That's why the epsps gene was not identified in these samples.

\subsubsection{Multiplex PCR}

Many of the PCR products for GMOs detection involve reactions that amplify a single target sequence. Multiplex PCR is a variation of the conventional technique in which two or more target sequences are simultaneously amplified in the same reaction. This method has high reliability, flexibility and reduced costs (James et al., 2003). Some studies have described the use of multiplex PCR as a rapid and convenient assay for the detection of GMOs. 
Permingeat et al. (2002) developed a multiplex PCR method for simultaneous detection of GMO in soybeans. Using only two pairs of primers from each cry $1 A(b)$ and pat genes, multiple reaction was optimized by combining the four primers at different concentrations. For the detection of transgenic soybean, multiplex PCR was developed for accurate and simultaneous detection of epsps and nos fragments, both corresponding to the introduced gene in Roundup Ready soybean, using two primer pairs, one for the 35S-epsps gene and the other for nos.

Rudi et al. (2003) designed a multiplex PCR-based assay for quantification of DNA. This method is based on two stages of PCR; in the first few cycles, bipartite primers containing the termination 5 'universal sequence and the 3 ' region of a specific sequence were used for each of the events that were analyzed genetically. The unused primers were then degraded with an exonuclease specific to single-stranded DNA. The second stage was performed containing only PCR primers complementary to the universal sequence of the 5 'region. The removal of the primers is essential for quantitative PCR. Oligonucleotides hybridized to internal fragments of the PCR products were then marked for specific sequences. The hybridization of labeled oligonucleotides to their complementary sequences in a DNA array enabled multiple detection, where quantitative information is obtained in the range of 0.1 to $2 \%$ for the different GMO analyzed. In this study, 17 different food and seed samples were examined using a 20-plex system for simultaneous detection of seven different GM maize lines (Bt176, Bt11, MON810, T25, GA21, and DBT418 CBH351). Germini et al. (2004a) proposed a method based on multiplex PCR for simultaneous detection of four types of GM maize (MON810, Bt11, Bt176 and GA21), one for soybeans (Roundup Ready) and two controls (for maize zein gene and the gene lectin for soybeans), on seeds, raw materials and processed foods. For this work, it was necessary to use seven pairs of primers in the same reaction, noting that the length of amplified segment was an important factor to detection of transgenic DNA in processed foods due to false negatives for DNA degradation in food processing. For this reason, primers amplifying segments with lengths no larger than $270 \mathrm{bp}$ were designed for the detection of GMOs even in highly processed products.

James et al.(2003) designed a multiplex PCR protocol to detect the 9 most common GM crops for soybeans (Roundup Ready), maize (event 176, Bt11, MON810, T14/25) and canola (GT73, HCN92/28, MS8/RF3, Oxy 235). Primer combinations were used allowing the identification of specific lines. In an identification system, simultaneous amplification was used rather than specific target detection for the identification of four GM maize lines. The non-specific amplification was used as a reliable tool for the identification of a GM maize line.

The initiator cry1A 4-3 '(antisense) recognizes two sites in the DNA extracted from transgenic corn event 176 resulting in the amplification of $152 \mathrm{bp}$ (expected) and $485 \mathrm{bp}$ (not expected) products. The last fragment was sequenced and confirmed that it corresponded to the gene cry $1 A(b)$. The simultaneous amplification has the ability to identify specific lines of GM, as well as identifying new GM lines containing similar transgenes.

\subsubsection{Real-time PCR (RTi-PCR)}

According to European regulations, the quantification is essential for labeling GMOs and satisfying these regulations. There are many research programs for the development of reliable methods, specific, standardized and quantitative detection of GMOs in food and seeds (Hernandez et al. 2004). The use of real-time PCR is a practical and quick as a 
quantitative method to detect GMOs in processed food samples (Ding et al., 2004, Hernandez et al. 2004). This PCR technique has made possible to quantify the initial amount of nucleic acids during PCR reaction without the necessity of further analysis (Mason et al., 2002). In addition, the amount of amplified DNA can be measured by fluorescence detection at the process, because the fluorescence emission produced in the reaction is proportional to the amount of DNA formed. This allows to know and record at all times the kinetics of the amplification reaction. The fluorescence detection systems used in real-time PCR can be of two types: specific intercalating agents and probes labeled with fluorophores (Costa, 2004). Vaiitilingom et al. (1999) developed a quantitative method for detection of transgenic maize events Maximazer 176 and Roundup Ready soybeans. The use of the detection system ABI Prism 7700 allowed the determination of the amplified product accumulation through a fluorescent probe (TaqMan). The use of Dutp and UNG in the PCR reaction eliminates contamination, which is the major source of false positives. Rott et al. (2004) evaluated two essays, one of conventional PCR to detect the presence of RR soybean. The second was realtime PCR to quantify the amount of RR soybean present in samples that were positive in the first essay. In quantitative tests, two groups were showed: soybean foods with traces of RR $(\leq 0.4 \%)$ suggesting a contamination of RR soybeans and soybean foods with high levels of RR soy.

\subsubsection{Capillary gel electrophoresis with laser-induced fluorescence}

With the increase of GMOs that have been developed for food applications, the ability to detect different transgenic sequences in a single reaction has become an important characteristic of any detection method (Garcia-Cañas et al., 2002b). However, there is a demand for new analytical methods which help to provide new and reliable information for the characterization of genetically modified foods (Garcia-Cañas et al., 2002a).

The use of PCR in combination with capillary gel electrophoresis (CGE) seems a good alternative for the detection of GMOs in food, based on DNA analysis. In combination with competitive PCR, the CGE analysis allows accurate detection and amplification of different transgenes, as an alternative to real-time PCR. However, the CGE UV detection has low sensitivity and usually cannot be applied to samples with concentrations below $10^{-6} \mathrm{M}$. The use of laser-induced fluorescence (LIF) in CGE dramatically increases the detection limit and linear dynamic range compared with that obtained with UV (Garcia-Cañas et al., 2002b). This technique involves a high degree of automation, use minimal amounts of samples and reagents, is capable of producing separations of PCR products with high efficiency, and has proven to be a good alternative to obtain accurate and sensitive quantification of DNA fragments amplified by PCR (Garcia-Cañas et al., 2004a).

Garcia-Cañas et al. (2002a), using capillary gel electrophoresis detected the presence of transgenic corn flour. The method is based on the extraction and PCR amplification of specific fragments of transgenic maize and subsequent analysis by capillary gel electrophoresis with UV detection and laser-induced fluorescence. A comparison between the two protocols for the detection of DNA based on UV absorption and laser-induced fluorescence was done, yielding a more sensitive detector with laser-induced. A sample of corn flour showed contamination not detectable by UV, which would generate a false positive. Additionally, Garcia-Cañas et al., (2002b) compared four different fluorescent intercalating agents for the detection of transgenic corn flour using capillary gel electrophoresis with laser-induced fluorescence. Fluorescent intercalating agents compared 
were: YOPRP-1, SYBR-GREEN-1, ethidium bromide and EnhanCE. It was shown that SYBRGREEN-I and Yopro-1 gave better detection limits than EnhanCE and ethidium bromide. Also, Garcia-Cañas et al. (2004b) devised a method for the simultaneous detection of five transgenic maize events using multiplex PCR followed by capillary electrophoresis laserinduced fluorescence. This method used Hexaplex PCR protocol for amplification of GM maize varieties Bt11, T25, MON810, GA21 and Bt176, demonstrating that the use of gel electrophoresis laser-induced fluorescence is very useful and informative for PCR optimization of multiple parameters such as time extension, the concentration of PCR buffer and primers. The method developed is very sensitive and also solves the problem of false positives.

\subsubsection{Microarrays}

The microarray technology can increase the ease and speed of analysis of PCR products. DNA microarray is an analytical system that allows simultaneous detection of many nucleic acid sequences in a sample. Each DNA sequence is represented by a covalent bond of an oligonucleotide probe on the modified surface of a piece of glass. The probes in the array are hybridized with fluorescent marker PCR products. Scanner analysis reveals the presence of labeled material containing the complementary sequences of those marked in the microarray (Germini et al., 2004b).

\subsubsection{Peptidic Nucleic Acids (PNAs)}

Peptide nucleic acids (PNAs) are analogues of oligonucleicos where the sugar-phosphate has been replaced by a pseudopeptide chain of the monomer N-aminoethylglycine (Germini et al., 2004b). Unlike nucleic acids, PNAs do not contain pentose phosphate groups. The main advantage of these biomimetic molecules compared to their natural analogues is their high affinity to liaise with DNA strands. The lack of electrostatic repulsion between them makes these links stronger than those between two strands of DNA (Gonzalez et al., 2005). Germini (2004b) reported the combination of microarray technology with PNAs for the detection of genetically modified soybean. Several PNAs were designed, synthesized and attached covalently to functional areas to build a microarray and to identify the constitutive gene lectin and the epsps gene. The effect of PNA length on signal intensity and specificity was assessed, as well as the conditions for the detection of PCR products of both single and double stranded. The best results were obtained with single-stranded PCR products and with long PNAs. The advantages of this method over other technologies include: PNAs are more efficient and hybrids are more stable than oligonucleotides, the PNAs are highly specific sequence and molecular microarrays allow simultaneous analysis of many sequences.

\subsubsection{Surface Plasmon Resonance (SPR)}

This method is based on biosensors capable of playing a biospecific interaction analysis (BIA) to monitor a variety of molecular reactions in real time. It is an optical technique that detects and quantifies changes in refractive index in the vicinity of a sensor chip surface in which the ligands are immobilized, allowing the detection of biomolecules (analytes) interacting with the ligand. If the ligand is single-stranded biotinylated DNA, SPR technology can easily monitor DNA-DNA hybridization in real time (Feriotto et al., 2003). 
Feriotto et al. (2003) designed and tested a protocol for SPR based on biospecific interaction analysis (BIA) for quantitative determination of GMOs. The protocol is based on the immobilization of multiple PCR products in a single cell flow sensor chip covered with Streptavidin and the injection of specific probes. Zein products labeled with biotin and Bt176 were immobilized on sensor chip SA taking advantage of the Streptavidin-biotin interaction. The approach is based on the immobilization of the same cell targets flow of two PCR products obtained by multiplex PCR using primers tagged with biotin and subsequent analysis by consecutive injection of a compatible nucleotide probe. To produce doublestranded target gene sequences, multiplex PCR was done using genomic DNA pattern with an excess of Bt-R primers and ZM-r-biot with its own Bt-F and biot-ZM-F labeled with biotin. This was done to minimize the presence of biotin labeling of primers not incorporated into the PCR mixture. The final products of multiple PCR, zein and Bt-176, were purified with Microcon-30. The agarose gel analysis and direct sequencing of PCR products confirmed the specificity of the PCR reaction. The results were compared with Southern blot and quantitative PCR using ABI Prism 7700.

\subsection{Techniques based on proteins identification}

\subsubsection{Enzyme-linked Immunosorbent Assay (or ELISA)}

In some cases the detection of GMOs in food is possible due to the presence of proteins encoded by transgenic sequences. This method only requires 4-6 hours to complete an analysis, it is easy to use and can effectively detect GMOs. Some of the restrictions on the use of ELISA for detecting transgenic proteins are denaturing of them during processing of food and the presence of false positive and negative reactions to other proteins. For these disadvantages, is estimated that the results of ELISA are reliable in 95\% of cases (Hsu-Yang et al., 2001).

\subsubsection{Lateral flow band}

This procedure represents an alternative to ELISA. The lateral flow band uses a combination of specific antibody to the protein of interest (capture antibody) with a conjugated antibody that is able to generate a colorimetric reaction (called detection antibody), which allows to visualize the presence of protein desired in the sample.

\section{Conclusion and perspectives}

Detection of transgenic residues in foods become a very actual theme because the increase of products derived from genetically modified organisms in the market shelves and the consumer demands for more strict regulations about labeling of this kind of products. Literature revised reports that short DNA trangenic sequence remain without degradation during most of the food steps processing, at the present time have been developed different techniques which are able to identify small traces of transgenic DNA or proteins. When soybean-based foods were elaborated using transgenic soybean, it was observed that the transgenic DNA and proteins were not degraded during the processing of these kinds of foods. In addition, it was found that the soybean-based commercial food processing did not affect the persistence of transgenic residues in food. With the development of multiplex PCR, it was possible to detect more efficient transgenic residues in plants and soybeanbased foods. 


\section{Acknowledgments}

The authors acknowledge the financial support provided by the Mexican Agency of Environmental and Natural Resources (SEMARNAT) through the projects: SEMARNATCONACYT2004-C01-00342, SEMARNAT-CONACYT2008-C01-108421and the project CONACYT-FOMIX COAH-2002-C01-4576. MLCG, CFG and VNGL thanks to CONACYT for the financial support during their MSc. Studies.

\section{References}

Ash, J.; Novak, C.S. \& Scheidel E. (2003). The fate of genetically modified protein from Roundup Ready soybeans in Laying Hens. Poultry Application Research Journal, 12, 242-245.

Barry, G.; Kishore G.; Padgette, S; Taylor, M.; Kolacz, K.; Weldon, M.; Eichholtz, D. R.; Fincher, D. \& Hallas, L. (1992). Inhibitors of amino acid biosynthesis: Strategies for imparting glyphosate tolerance to crop plants. Current Topics in Plant Physiology, 7, 139-145.

Batiste, R.; Nunes, B.; Carmo, M.; Cardoso, C.; Sao José, H.; Bugalho de Almeida, A.; Manique, A.; Bento, L.; Pinto, C. \& Oliveira, M. (2005). Lack of detectable allergenicity of transgenic maize and soybean samples. Ameican Academy of Allergy, Asthma and Immunology, 116, 2, 403-410.

Burks, A.W.; Brooks, J.R. \& Sampson, H.A. (1988). Allergenicity of major component proteins of soybean determined by enzyme linked immunosorbent assay (ELISA) and immunoblotting in children with atopic dermatitis and positive soy challenges. Journal Allergy Clinical Immunology, 81, 1135-1142.

Burks, W. A. \& Fuchs, R.L. (1995). Assessment of the endogenous allergens in glyphosatetolerant and commercial soybean varieties. Journal Allergy Clinical Immunology, 96, 1008-1010.

Cantu-Iris, M. (2006). Thesis Development of a multiplex PCR method for detection of transgenic genes in plants, Food Research Department, Universidad Autonoma de Coahuila, Saltillo, Coahuila, Mexico. pp. 1-4

Castro-Soto, G. \& Zinn R. (2001). Bulletin Transgenics in Mexico, San Cristóbal de las Casas, Chiapas, México, pp. 1 to 7

Costa, J. (2004). Real Time Polymerase Chain Reaction (PCR). Infectious Diseases and Clinical Microbiology, 22, 5, 299-305.

Cruz-Flores, Y. A. (2005). Thesis detection of genes and transgenic protein in commercial foods based on soybean (Glycine max (L.) Merr.) Food Research Department, Universidad Autonoma de Coahuila, Satillo, Coahuila, Mexico, pp. 5-8.

Diario Oficial de la Federación (2005). Ley de Bioseguridad de Organismos Genéticamente Modificados. Disponible en http://www.cddhcu.gob.mx/leyinfo/

Dill, G.M.; CaJacob, C. A. \& Padgette, S. R. (2008). Glyphosate-resistant crops: adoption, use and future considerations. Pest Management Science. Jhon Wiley \& Sons, Ltd. 64: 4, pp. 326-331(6).

Ding, J. ; Jia, J. ; Yang, L. ; Wen, H. ; Zhang, C.; Liu W. \& Zhang D. (2004). Validationn of a Rice Specific Gene, Sucrose Phosphate Synthase, Used as the Endogenous Reference Gene for Qualitative and Real-Time Quantitative PCR Detection for Transgenes. Journal of Agricultural and Food Chemistry, 52, 3372-3377. 
Feriotto, G.; Borgatti, M.; Mischiati, C.; Bianchi, N. \& Gambari, R. (2002). Biosensor Technology and Surface Plasmon Resonance for Real-Time Detection of Genetically Modified Roundup Ready Soybean Gene Sequences. Journal of Agricultural and Food Chemistry, 50, 955-962.

Feriotto, G.; Gardenghi, S.; Bianchi, N. \& Gambari, R. (2003). Quantization of Bt-176 Maize Genomic Sequences by Surface Plasmon Resonance- Based Biospecific Interaction Analyses of Multiplex Polymerase Chain Reaction (PCR). Journal of Agricultural and Food Chemistry, 51, 4640-4646.

Garcia-Cañas, V.; Gonzalez, R. \& Cifuentes, A. (2002a). Detection of Genetically Modified Maize by Polymerase Chain Reaction and Capillary Gel Electrophoresis with UV Detection and Laser.Induced Fluorescence. Journal of Agricultural and Food Chemistry, 50, 1016-1021.

Garcia-Cañas, V.; Gonzalez, R. \& Cifuentes, A. (2002b). Ultrasensitive Detection of Genetically Modified Maize DNA by Capillary Gel Electrophoresis with LaserInduced Fluorescente Using Diferent Fluorescent Intercalating Dyes. Journal of Agricultural and Food Chemistry, 50, 4497-4502.

Germini, A.; Zanetti, A.; Salati, C.; Rossi, S.; Forre, C.; Schmid, S. \& Marchelli, R. (2004a). Development of a Seven-Target Multiplex PCR for the Simultaneous Detection of Transgenic Soybean and Maize in Feeds and Foods. Journal of Agricultural and Food Chemistry, 52, 3275-3280.

Germini, A.; Mezzelani, A.; Lesignoli, F.; Corradini, R.; Marchelli, R.; Bordoni, R.; Consolandi, C. \& Bellis, G. (2004b). Detection of Genetically Modified Soybean Using Peptide Nucleic Acids (PNAs) and Microarray Technology. Journal of Agricultural and Food Chemistry, 52, 4535-4540.

GM Crop Database ACS-GM001-8, ACS-GM003-1, ACS-GM002-9, ACS-GM-005-3 ACSGM006-4, 2010.

GM Crop Database BPS-CV127-9, 2010.

GM Crop Database DD-026005-3, 2010.

GM Crop Database DP-305423-1, 2010.

Goldburg, R.J. (1992). Environmental Concerns with the Development of Herbicide-Tolerant Plants. Weed Technology, 6, 647-652.

Gonzalez, M. S. (2004). Thesis Detection of Genes and Proteins in Transgenic Soybean Processed Foods. Food Research Department, Universidad Autonoma de Coahuila. Saltillo, Coahuila, México.

Gonzalez, V.; Garcia, E.; Ruiz, O. \& Gago, L. (2005). Applications of Biosensors in the Food Industry. Informe de Vigilancia Tecnológica. Madrid, España.

Hernandez, M.; Duplan, M.; Berthier, G.; Vaitilingom, M.; Hauser, W.; Freyer, R.; Pla, M. \& Bertheau, Y. (2004). Development and Comparison of Four Real-Time Polymerase Chain Reaction Systems for Specific Detection and Quantification of Zea mays L. Journal of Agricultural and Food Chemistry, 52, 4632-4637.

Hernandez, V.L. 2007. Thesis Adaptation of a multiplex-PCR technique for detection of transgenic genes in commercial foods. Food Research Department, Universidad Autonoma de Coahuila, Satillo, Coahuila, Mexico, pp. 25-58.

Holt, J.S.; Powles, S.B. \& Holtum, J.A.M. (1993). Mechanisms and Agronomic Aspects of Herbicide Resistance. Annual Review Plant Physiology Plant Molecular Biology, 44, 203-229. 
Hsu-Yang, L.; Chang, J. W. \& Shih, D. Y. (2001). Detection of Genetically Modified Soybeans by PCR Method and Immunoassay Kits. Journal of Food and Drug Analysis, 9, 160166.

International service for the acquisition of applied agricultural biotechnology (ISAAA) (2007). Global status of commercialized biotech/gm crops: 2006. ISAAA Bried 352006.

Executive Summary

en

http://www.isaaa.org/Resources/Publications/briefs/35/executivesummary/def ault.html (December 18 ${ }^{\text {th }}, 2007$ )

Isanga, J. \& Zhang, G. N. (2008). Soybean Bioactive Components and their Implications to Health-A Review. Food Reviews International, 24, 2, 252-276.

James, C. (2006). Global Status Commercialized Biotech/GMCrops:2006. ISAAA Biref No. 35. ISAAA: Ithaca, NY. ISBN 1-892456-40-0

James, D.; Scmidt A.; Wall E.; Green M. \& Masri A. (2003). Reliable Detection and Identification of Genetically Modified Maize, Soybean and Canola by Multiplex PCR Analysis. Journal of Agricultural and Food Chemistry, 51, 20, 5829-5834.

Jeng, S.; Shyu, Y. \& Pan, T. (2006). Detection of the Genetically Modified Soybeans in Processed Foods. Analytical, Nutritional and Clinical Methods, 98, 3, 575-579.

Krimsky, S. \& Wrubel, R.P. (1996). Agricultural Biotechnology and the Environment: science, policy and social issues. University of Illinois Press, Urbana.

Macias-de la Cerda C.G. (2006). Thesis Development of a multiplex PCR method for detection of accompanying segments of transgenic plants. Food Research Department, Universidad Autonoma de Coahuila, Saltillo, Coahuila, Mexico. pp. 24

Malik, J., G.; Barry, G. \& Kishore, T. (1989). The herbicide glyphosate. BioFactors, 2, 17-25.

Marshall, A. (2007). GM soybeans and health safety-a controversy reexamined. Nature Biotechnology, 25, 9, 981-987.

Mason, G.; Provero, P.; Veira, A. M. \& Accotto, G. P. (2002). Estimating the number or integrations in transformed plants by quantitative real-time PCR. BMC Biotechnology, 2, 1-10.

Massieu-Trigo, Y.C. (2009). Crops and transgenic foods in Mexico: The debate, actors and socio-political forces. Argumentos, 22, 59. (In Spanish)

Messina, M. (2008). Investigating the optimal soy protein and isoflavone intakes for women: a perspective. Women's Health, 4, 4, 337-356.

Messina, M. \& Lane, B. (2007). Soy protein, soybean isoflavones and coronary heart disease risk: where do we stand? Future Lipidology. Future Medicine, 2, 1, 55-74.

National Agricultural Statististics Service (NASS) (2009). Acreage. Agricultural Statistics Board, U.S. Department of Agriculture. Washington, D.C. U.S.A. 40 p. Releases June 30, 2009

Ogawa, F.; Tsuji, H. \& Bando, N. (1993). Identification of the soybean allergenic protein, Gly $m$ Bd 30K, with the soybean seed 34-kDa oil-body associated protein. Bioscience, Biotechnology and Biochemistry, 57, 1030-1033.

Padgett, S. R.; Kolacz, K. H.; Delannay, X.; Re, D. B.; LaVallee, B. J.; Tinius, C. N.; Rhodes, W. K.; Otero, Y. I.; Barry, G. F.; Eichholtz, D. A.; Peschke, V. M.; Nida, D. L;, Taylor, N. B. \& Kishore, G. M. (1995) Development, identification and characterization of a glyphosate-tolerant soybean line. Crop Science, 35, 1451-1451. 
Permingeat, H.; Reggiardo, M. \& Vallejos, R. (2002). Detection and Quantification of Transgenes in Grains by Multiplex and Real-Time PCR. Journal of Agricultural and Food Chemistry, 50, 4431-4436.

Qaim, M. \& Traxler, G. (2005). Roundup Ready soybeans in Argentina: farm level and aggregate welfare effects. Agricultural Economics, 32, 1, 73-86.

Ragasa, C. \& Pehu, E. (2008). Capturing the Benefits of Genetically Modified Organisms for the Poor. Development Outreach, 10, 3, 38-40.

Rincon S. F.; Ruíz, N. A. \& Serrato V.M. (1999). Granos transgénicos. Editorial Buenavista. pag 1-31.

Rissler, J. \& M. Mellon (1996). The Ecological Risks of Engineered Crops. MIT Press, Cambridge.

Robinson, R.A. (1996). Return to Resistance: breeding crops to reduce pesticide resistance. AgAccess, Davis. Scotish Crop Research Institute 1996. Research Notes, Genetic Crops Community Institute.

Rott, M.; Laerence, T.; Wall, E. \& Green, M. (2004). Detection and Quantification of Roundup Ready Soy in Foods by Convencional and Real-Time Polymerase Chain Reaction. Journal of Agricultural and Food Chemistry, 52, 5223-5232.

Rudi, K..; Rud, I. \& Holck, A. (2003). A Novel Multiplex Quantitative DNA Array Based PCR (MQDA-PCR) for Quantification of Transgenic Maize in Food and Feed. Nucleic Acids Research, 31, 11, 1-8.

Tavva, V.; Kim, Y.; Kagan, I.; Dinkins, R.; Kim, K. \& Collins, G. (2007). Increased atocopherol content in soybean seed overexpressing the Perilla frutescens $\gamma$-tocopherol methyltransferase gene. Plant Cell Reports, 10, 61-70.

Tripp, R. (1996). Biodiversity and Modern Crop Varieties: sharpening the debate. Agriculture and Human Values, 13, 48-62.

Vaïtilingom, M.; Pijnenburg, H.; Gendre, F. \& Brignon, P. (1999). Real-Time Quantitative PCR Detection of Genetically Modified Maximizer Maize and Roundup Ready Soybean in Some Representative Foods. Journal of Agricultural and Food Chemistry, 47, 5261-5266.

Völlenhofer, S.; Burg, K..; Schmidt, J. \& Kroath, H. (1999). Genetically Modified Organisms in Foods Screening and Specific Detection by Polymerase Chain Reaction. Journal of Agricultural and Food Chemistry, 47, 5038-5043. 


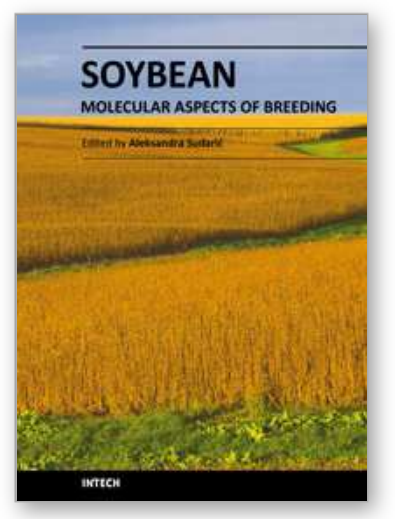

\author{
Soybean - Molecular Aspects of Breeding \\ Edited by Dr. Aleksandra Sudaric
}

ISBN 978-953-307-240-1

Hard cover, 514 pages

Publisher InTech

Published online 11, April, 2011

Published in print edition April, 2011

The book Soybean: Molecular Aspects of Breeding focuses on recent progress in our understanding of the genetics and molecular biology of soybean and provides a broad review of the subject, from genome diversity to transformation and integration of desired genes using current technologies. This book is divided into four parts (Molecular Biology and Biotechnology, Breeding for Abiotic Stress, Breeding for Biotic Stress, Recent Technology) and contains 22 chapters.

\title{
How to reference
}

In order to correctly reference this scholarly work, feel free to copy and paste the following:

Mónica L. Chávez-González, Carolina Flores-Gallegos, Víctor M. García-Lazalde, Cristóbal Noé Aguilar and Raúl Rodríguez-Herrera (2011). Transgenic Residues in Soybean-based Foods, Soybean - Molecular Aspects of Breeding, Dr. Aleksandra Sudaric (Ed.), ISBN: 978-953-307-240-1, InTech, Available from:

http://www.intechopen.com/books/soybean-molecular-aspects-of-breeding/transgenic-residues-in-soybeanbased-foods

\section{INTECH}

open science | open minds

\section{InTech Europe}

University Campus STeP Ri

Slavka Krautzeka 83/A

51000 Rijeka, Croatia

Phone: +385 (51) 770447

Fax: +385 (51) 686166

www.intechopen.com

\section{InTech China}

Unit 405, Office Block, Hotel Equatorial Shanghai

No.65, Yan An Road (West), Shanghai, 200040, China

中国上海市延安西路65号上海国际贵都大饭店办公楼 405 单元

Phone: +86-21-62489820

Fax: $+86-21-62489821$ 
(C) 2011 The Author(s). Licensee IntechOpen. This chapter is distributed under the terms of the Creative Commons Attribution-NonCommercialShareAlike-3.0 License, which permits use, distribution and reproduction for non-commercial purposes, provided the original is properly cited and derivative works building on this content are distributed under the same license. 